\title{
Pacing Intermittently
}

National Cancer Institute

\section{Source}

National Cancer Institute. Pacing Intermittently. NCI Thesaurus. Code C63066.

Problem associated with the failure of pacing device for a limited period of time, following which the item recovers its ability to perform its required function without being subjected to any external corrective action. Note: such as failure is often recurrent. 